\title{
Indian Cinema in an Age of Globalization
}

\section{Sugimoto Yoshio}

India's commercial cinema is attracting popular attention in Japan, and a range of Western, Asian, African and Middle Eastern countries. Films from Bombay (Mumbai), the national center of Hindi production known as "Bollywood", together with regional movies from Tamil Nadu, are increasingly popular.

Yet, as Bhattacharya wrote, "Indian films were relatively unknown in the West", and "even if they were known, it might have not been worth to know, especially when set against the cinematic "quality" of art house films by Indian cinematic auteurs such as Satyajit Ray, Shyam Benegal, or Ritwik Gatak."

During the 1990s the Indian commercial cinema became a subject of academic interest through the influence of the Cultural Studies. Especially, after 1995 - the centenary year of the birth of movies - the main topic of interest was examining the social, political and cultural aspects of the Indian commercial cinema, particularly in relation to nationalism.

In this essay, I discuss the diversity and dynamics of Indian commercial cinema in an age of globalization. Particular emphasis is focused upon the influence of the emerging new urban middle class that have come to the forefront of Indian life following a decade of economic liberalization. Attention is also centred upon the impact of technological developments such as cassettes, CDs, DVDs, and satellite TV on the Indian cinema. Finally, there is a discussion of the influence of overseas Indians, including non-resident Indians (NRIs) and persons of Indian origin (PIOs) on the nature and direction of the Indian cinema.

\section{India - the world largest film producer}

India is the world's largest film producer. At its peak in 1990 India produced 949 films. After that, television, video and satellite broadcasting became popular and alternative entertainment formats multiplied. Consequently, annual production has fallen to between 600 and 700 films paralleling the frequent closures of cinemas. Ranked after India are the United States and Philippines with annual outputs of 400 films followed by Japan with 200 films.

1). Bhattacharya, N. 'A "basement" Cinephila: Indian Diaspora women watch Bollywood' South Asian Popular Culture, 2, 2004, p. 161.

2) See (1) Chakravarty, S. S., National Identity in Indian Popular Cinema 1947 - 1987, Delhi: Oxford University Press, 1998 (1993). (2) Garga, B. D., So Many Cinemas: The Motion Picture in India. Mumbai: Eminence Designs, 1996. (3) Nandy, A., The Secret Politics of Our Desires: Innocence, Culpability and Indian Popular Cinema. Delhi: Oxford University Press, 1996. (4) Kazmi, F., The Politics of India's Conventional Cinema: Imaging a Universe, Subverting a Multiverse. New Delhi: Sage, 1999.

3) See (1) Sugimoto, Y., Indo Eiga e no Shoutai (An Introduction to Indian Cinema) Seikyu-sha, 2002. For encyclopaedical references, see (2) Garga, B. D., So Many Cinemas: The Motion Picture in India. Mumbai: Eminence Designs, 1996. and (3) Rajadhyaksha, A. \& Willemen, P., Encyclopaedia of Indian Cinema. $2^{\text {nd }}$ ed., New Delhi: Oxford University Press, 1998. 
India's population is approximately one billion and its land area is equal to Western Europe. There are more than 12,000 cinemas that attract 4 billion people each year. Annual income is 500 million rupees (approximately 1,300 million yen) and one million people are directly employed in film production. Japan, with roughly one-eighth of India's population, has 1,800 cinemas and an annual patronage of 150 million.

For Indians films are the highest form of exclusive entertainment that can be enjoyed safely by everyone. Poor people prefer to go to cinema at the expense of their meals. To that extent, Indian movies are loved by the masses. The atmosphere of cinemas in India allows everyone to enjoy their time there. The audience alternates between joyfulness and sorrowfulness with the development of the story. Cheers are reserved for exceptional and intelligent dialogue. Patrons dance during song scenes and clap their hands when happy endings occur demanding rewards for good deeds and punishment for evil ones.

This happiness derives from the role of the cinema as important meeting places. Among the audience, irrespective of age or gender-people in groups are conspicuous. Once I went to watch an adult foreign film and parents bringing their children to attend surprised me. However, Indian films are produced for the entire range of the population. An average movie takes about three hours. Within this time span various interesting things happen to satisfy everybody's curiosity. Therefore, movies that are difficult to comprehend or are devoid of educational purpose are unwelcome.

Critics argue Indian films are virtually identical and lack artistic depth. These low-browed entertainment movies are attractive to the masses as they provide "dreams and illusions".

The people's enthusiasm for cinema seems overwhelming. Provided moviegoers keep on coming the cinema the film will continue. Ham apke hain koun (HAHK, 1994) was one of the biggest hits in Indian film industry. After the film's release, it was shown for over one year and earned the highest revenue ever recorded in the entertainment industry. A student in Mumbai (Bombay) went to the cinema everyday for a year to watch the same film. He even kept the daily tickets he had purchased for evidence.

Conversely, the release of Padayappa produced in Tamil Nadu by the superstar Rajni Kant had been stalled for two years. After a colorful parade it was finally released in April 1999. The film was the hottest topic in each town and shown in all eighty of Tamil Nadu's cinemas simultaneously. All seats were booked in advance for a whole month. The fans' enthusiasm was so great and infectious that on the day of release, they invaded the stage to purify the screen with "holy fire" as they revered Rajni as God. When the purification rites were being performed the screen caught alight. Once the fire was doused the spectators demanded the theater manager project replay the song scenes again. They threatened that if any bracket of songs by the musical director, A. R. Rahman, were omitted they would burn the cinema down. With such devotion it was not surprising that Padayappa broke box-office records by running for over one hundred days in each of the province's cinemas. Indeed, many similar stories could be told.

Other film stars even caused political trouble. For instance, a riot occurred on the death of M. G. Ramachandran (MGR, 1917-1987) ' of Tamil Nadu. He was the greatest superstar ever produced by Tamil films and a charismatic politician. He had served as the State Chief Minister since 1977, 
and was especially popular among the poor because of his welfare schemes. When MGR passed away on the Christmas Eve in 1987, the entire state witnessed a general strike and the riot. At the Madras cremation powerful central politicians were prominent among the crowd of 4 million mourners from all over Tamil Nadu. Not surprisingly, the confusion at the funeral was unimaginable.

In 1990 a similar incident occurred. A false rumor was spread that the great Tamil star Sivaji Ganesan had passed away. The rumor prompted excited fans to throw stones at buses and taxies, which brought the entire transport system to a halt. This led to a general strike (bandh) before it was discovered that the rumor was untrue. When Sivaji Ganesan passed away eleven years later the mourning period was again accompanied by a big riot.

This situation was reminiscent of the situation a year earlier when abduction of a film star in Karnataka State, South India, stirred the entire population. On 31st July 2000, a mysterious bandit named Verappan, who had been terrorizing India for a decade, kidnapped the great Kannada star Raj Kumar (1929-). Veerappan was reputed to be the southern Indian version of the "Bandit Queen" - the late Phoolan Devi. Since 1980 he was reputed to be a smuggler who poached sandalwood and elephants in the forests. Reportedly, Verappan had killed several dozen forest police officers seeking to capture him. Following the abduction of Raj there was turbulence in Karnataka State. In particular, there was violence in the state capital, Bangalore, which led a general strike that newspapers reported as an "undeclared bandh". City life was paralyzed. Only train services were in operation. All buses, taxies and trucks were out-of-service. Shops and educational institutions were forced to close down. The more fanatical fans of Raj Kumar even went on hunger strike. As there was delay in Raj Kumar's release, some fans self-immolated.

These incidents not only demonstrate the great popularity of the cinema in India but also reveal that the behavior of the stars greatly influence the political and social situation in local states and even in the nation as a whole. Although cinema is representative of India's entertainment industry in the twentieth century, it remains of pivot concern in the new millennium.

\section{What is Indian cinema?}

\section{(1) India, a multilingual country}

When one says "Indian cinema", the term covers a whole gamut of activities; but what does "Indian Cinema" actually mean? India is a multi-lingual country. There are a few thousand languages, and they can be divided into four big groups: Indo-European, Dravidian, Tibetan-Burmese, and Austro-Asian. The two official languages of central government are English and Hindi. Another eighteen languages, including Sanskrit and the official language of each state, are approved by the central government. In multilingual India, films are not only produced in Hindi but also in over ten other languages. However, mainstream cinema in India is of course Hindi but it accounts for less than one-fifth of the films produced. The bulk of movies are produced in South India using Tamil, Telegu, Kannada, and Malayalam together. The output is between 400 and 500 films a year, which surpasses the combined Hong Kong and Japanese total. In short, In- 
dian cinema is vast; also it is diverse.

In India three great cities, Bombay in the West, Calcutta in the East, and Madras in the South, are the centers of film production. Although the capital Delhi had been developed since the 12th century by Muslim kings it exerted little influence though Bombay, Calcutta and Madras were merely isolated villages or small towns. Under British rule, Bombay, Calcutta and Madras became major colonial cities. During the nationalistic fervor of the 1990s the names of these cities were changed, Indian style, to Mumbai (Bombay), Kokotta (Calcutta) and Chennai (Madras). By then the three cities had already capitalized on their colonial entrée into cinema and possessed the characteristics of modern metropolises.

Heavily influenced by British drama, Bombay, Calcutta and Madras were popular theater towns. Bombay was the centre of Marathi theater together with Pune, Calcutta was the focus of the Bengali language theater, and Madras was the base for Tamil theater. Conversely, Delhi? the center of Hindi region? kept aloof from cinema production, presumably due to the absence of an early theatre tradition.

\section{(2) Entertainment cinema and art cinema}

There are two streams in Indian movies: the entertainment cinema and the art cinema. Almost all Indian films belong to the former and are typified by Muthu (1995), which has had a boom in both India and Japan. Characteristics of India's "entertainment cinema" tradition include:

1. Melodrama overflowing with songs and dances,

2. Hybrid formation, including an admixture of joyful factors,

3. The development of a typical conversation,

4. A happy ending,

5. An "escapist" tendency, as they avoid serious social issues.

In the 1950s "art cinema" became prominent as an independent genre through Satyajit Ray's films. Since then Indian cinema has been divided into two streams. Over time the artistic factor of the elitist art cinema has become more sophisticated and the entertainment factor more pronounced.

The origins of the Indian "art cinema" can be traced to the Second World War and immediate post-war period when producers sought to satisfy the European tastes. These movies oriented their Indian scenes towards Western interests. However, art cinema contributed only a small fraction of Indian film output. Few of them could succeed in the entertainment realm. Although Satyajit Ray's films were highly rated abroad as art cinema their orientation towards foreign tastes raises the issue as to whether they were "Indian" cinema or not.

During the 1950s, when Ray's films were in vogue Asian cinema received attention in both Europe and America. Coincidentally, Akira Kurosawa's Rashomon (1950) participated in the Venice International Film Festival and received an Academy award for the Best Foreign Film in 1951. Later, Satyajit Ray received his initial international acclamation. At the time, both Kurosawa and Satyajit Ray were considered as the best Asian directors.

Indian art films are mainly concentrated around Bengal and Kerala, which are noted both for their communist leanings and intelligentsia. Most art films are produced in the regional languag- 
es, notably Bengali and Malayalam. Consequently, they are little known in other regions where languages other than Bengali or Malayalam are spoken. This shortcoming is offset by their foreign appeal. Therefore, art films are exceptional in simultaneously combining both regional characteristics, stemming form language differences, and internationalism.

During the late 1960s "new cinema" was introduced as a compromise product between art and entertainment. Although the artistic elements were retained, commercial factors were also brought into the equation determining their production decision. The new cinema only lasted a decade. It could not withstand the criticism of their artistic merits by Satyajit Ray and poor boxoffice results. Currently, Sham Benegal's films have revived this genre.

\section{(3) Globalization and hybridization of Indian cinema}

Recently, Indian cinema has grown strongly overseas which complicates its profile. For instance, Salaam Bombay (1988), Mississippi Masala (1991) and Kamasutra (1997) have become popular internationally and generated great debates among domestic critics. Their director, Mira Nair, was born in Orissa and educated at Harvard. She now lives in Canada, and her activities are centered upon North America. Further, Shekar Kapur (1945-), a member of the renowned Kapur family, became famous through his Mr. India (1987). He drew further international attention through his Bandit Queen (1994) and Elizabeth (1999), the latter was set in 16th century England and was totally devoid of any Indian-ness.

In the 2002 Academy Awards, the Hindi film Lagaan (2001), drew world attention though it did not receive an Oscar. At the Cannes Film Festival the new production Devdas (2002) was shown but did not receive a Prix d'Or. Although neither was successful their favorable reception restored Indian cinema's international reputation. This reputation was further bolstered by the success of the Indian musical Bombay Dreams in London. This success underlines the broadening of the global appeal of Indian arts and entertainment beyond the cinema.

Non-resident Indians in America and Europe play an important role in widening the market for Indian cinema. Better quality and higher-grade videos catering to these markets are distributed through Singapore and London immediately following their release in Indian theaters. These developments have raised issues over the transfer of performing rights and problems pertaining to copyright to underline Japan is not alone in this matter.

\section{Globalizing Indian films}

\section{(1) Overflowing number of copies}

Indian film industry reached its peak production of 948 in 1990 and experienced a drop to 600 -700 films by the end of the decade. This downturn reflects the propagation of television and satellite broadcasting becoming cheaper. Consequently, leading cinema managers left the profession, which, in turn, depleted the industry's morale. A wave of economic efficiency contributed to the further erosion of Indian cinema. Film production has always had a great gambling element. Innumerable pieces of equipment are required and many workers have to mobilize. Often 
success or failure in the expensive business of filmmaking resembles the difference between heaven and hell.

Over time various type of media have been employed to publicize the Indian cinema. Originally, the most effective strategy was the insertion of songs. Booklets containing the songs, or collections of hit songs were published regularly to boost a film's popularity. Since the 1950s posters on street corners and big advertising boards have been used and, though the print media has declined, they are still in use.

The audio-visual media that traces its origins to the introduction of the gramophone record in 1902 has progressively superseded print culture. In 1908 the Indian Gramophone opened its Calcutta factory and His Masters Voice (HMV) continued to appear on record labels despite the firm being acquired by EMI, which were used in radio broadcasts.

In 1975 the cassette tape replaced the HMV record in India. Amithab Bachhan was a superstar in the late 1970s and 1980s when the cassette tape ruled over the Indian cinema. The cassette was a revolutionary technological device because, unlike the record, the tapes could be easily copied. During 1990s the combination of tape-recorder-cum-radio became so popular that the demand for cassette tapes grew enormously. In 1994 India Today weekly published a special issue titled Music Mania. This special issue coincided with the Indian cinema's release of its great historical hit HAHK (1994). During 1993-94 the best seller was Baazigar (1993) whose musical director was the popular Anu Malik, which sold more than 10 million copies. Immediately after its release $H A H K$ occupied fourth position selling more than 4 million copies. These sales numbers were incredible.

During the mid-1980s the musical market's turnover was Rs. 1,000 million which, because of its monopoly, accrued to the HMV Company. In the 1990s the Venus Record Company came to the fore together with other companies such as Tips, Time and Weston, which exerted pressure upon HMV's position. As early as 1985 the Venus Company had reduced royalties from Rs. 100,000 to Rs. 50,000 and cut the price of tape sales from Rs. 35 to Rs. 25 per item. In 1990 the Venus Company has released Ashiqui (1990) and experienced sales in excess of Rs. 20 million, coinciding with the expansion of the cassette market. Royalties also skyrocketed from about Rs. 1 million to Rs. 10 million. From then onwards the cassette music market has expanded at an annual rate of $25 \%$, the musical market of Hindi cinema alone reached as high as Rs. 3,000 million (approximately 8,000 million Yen).

The most prosperous period for cassettes was during the mid-1990s. However, after the compact disc arrived the demand for cassettes collapsed. Mainstream media shifted to digital technology. Rental video shops that had proliferated in the cities started fire sales and were uncertain whether to close down, or changeover to video $\mathrm{CD}$. The merit of digital technology is that when you dub from the original the quality of the copy is as good as the original. Simultaneously, the copy culture threatened on-the-spot production of original films. Internationally, films are subject to strict copyright rules and India ascribes to the legislation. However, original production rights in India are very weak and there is always the possibility of commencing with a few original prints and then diverting them via various routes for further illegal reproduction. Thus, original prints, with proper international rights, go abroad simultaneously with illegal prints. 
Overseas production rights for current Indian films, particularly for South Indian Tamil films, are sold to Singapore and Malaysia where Indian immigrants have settled in large numbers. Apparently, Hindi and Malayalam films flow into Arab countries. Originally, sponsors released Tamil films as soon as they were completed but some films have never been distributed overseas. Maintaining copyright is a major problem given the widespread availability of suitable technology. Symptomatic of the problem is that a package of three Indian films, each of three hours duration, is available in the Indian residential areas of Singapore for 15 Singapore dollars (approximately 1000 Yen).

The propagation of $\mathrm{CD}$ writers and video captures has stimulated the flow of copies. Some city shops openly carry on the business of digitalizing captured videotapes. While there is resistance to this activity in India, it is, at best, token. Reproduction in adjacent countries is quite active. However, it is through these technological advancements that Indian cinema has rapidly infiltrated the outside world.

\section{(2) Impact of satellite television}

Suddenly, India is in the television age. Over the past few years the percentage of households receiving satellite broadcast has become very high. Every house, irrespective of town or village watches satellite broadcasts. An average of 30 channels can be viewed in villages and towns, and more than 60 channels in the big city hotels.

The attraction of the Indian satellite channels, needless to say, is the cinema. If drama or cinema are not being screened there are hit parades focusing on song and dance sequences. There is no denying that the spread of television is responsible for the downfall of the cinema. Of course, when one can sit at home and relaxingly watch films on video or television, the chance of visiting the cinema decreases. This is the reason why the number of theaters in cities is in decline. Cinemas that have closed down are turned into wedding halls, show rooms for automobiles, or simply left to collapse and decay. Although watching films on big theater screens is declining, it does not mean that the popularity of cinema is withering.

The popularity of television drama accounts for the slump in cinema going and the flow of workers from the cinema world to television. Even during the initial period of television in Japan, the transfer of workers from the film production to television created a problem. The cinema world entered into an agreement with television producers to restrict the flow of actors from the large to the small screen. The agreement was ineffectual and the Japanese cinema production has declined.

The current march from the film to television production in India cannot be halted. Film production is a gamble. Production not only needs a large workforce and money but also box-office success. Conversely, television programs generate continuous income flows. Although there has been no exodus of great directors and actors to television the portents are ominous.

Among various television dramas household themes are the most popular. Dramas involve retelling the same old stories distilled from the cinema: disharmony between the mother-in-law and daughter-in-law, wantonness and violence of the husband, rape, family feuds for wealth, and juvenile delinquency. Since the 1980s genealogic rape had become popular in films but this 
genre has been transferred to television dramas.

The late 1990s was the heyday of television dramas. In July 2000 the quiz program Kaun banega crorpathi $(\mathrm{KBCP})$ commenced on television and the entire nation shifted from drama. This quiz program was the Hindi version of the popular English program Who wants to be a millionaire. Amitabh Bachhan, an unparalleled super star, became the quizmaster of the program rivaling Japan's Mino Monta. The program was scheduled nightly from Monday to Thursday at 9 p.m. This quiz program was so popular that late Indian diners had to change their schedules. Quiz participants were satisfied to share the same stage with Amitabh. Once they were qualified in the preliminaries they experienced the supreme bliss of sitting face-to-face with Amitabh. Once he was in line with the participant he delivered the questions in chaste Hindi using his baritone voice and displaying his attractive personality. All these factors contributed to Amitabh attracting a new legion of fans to television and away from the cinema.

\section{(3) Preeminence of foreign markets}

The advancement of the Indian cinema into foreign markets is reflected in their export earnings. Indeed, Sushma Swaraj, the Minister for Information and Broadcasting has estimated that the export value of Indian cinema has increased from Rs. 2,500 million (approximately 6,000 million Yen) in 1999 to Rs. 4,500 million (about 12,000 million Yen) in 2002. By 2010 the Minister expects sales of Rs. 9,000 million (approximately 26,000 million Yen) in 2010. In order of importance, the major overseas markets are the Middle East, the United Kingdom, Malaysia followed by the

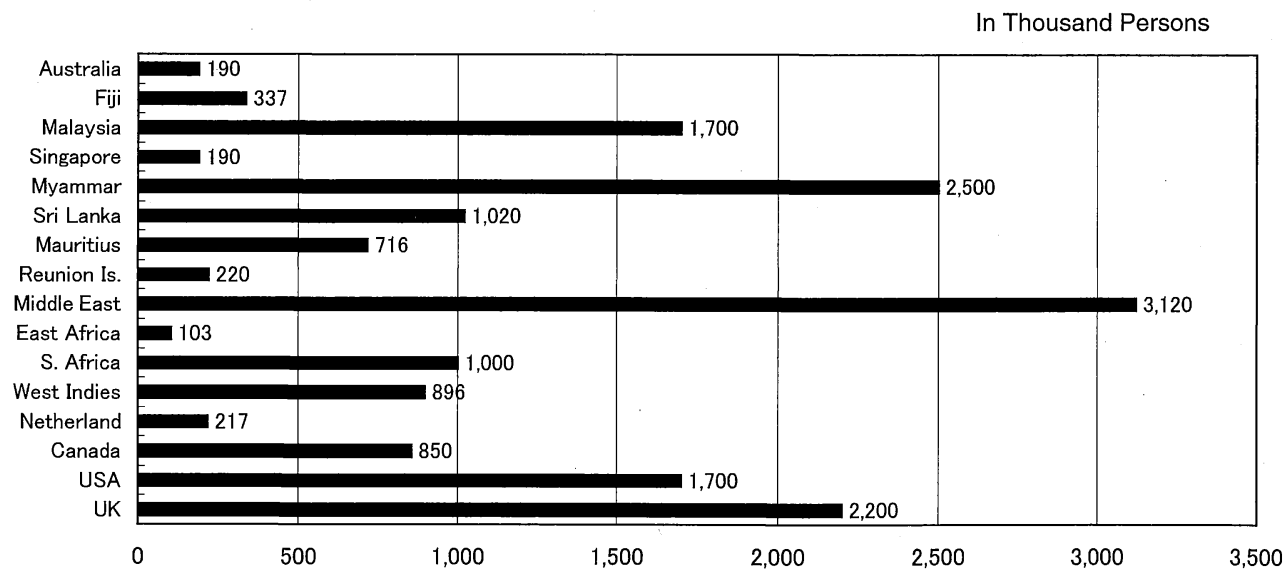

Figure 1. Estimated World Distribution of Overseas Indians in the Early 1990s Note: Overseas Indians include both Non-Resident Indians and Persons of Indian Origin. Source: Far Eastern Economic Review, 23 Jan. 2003, and INDIAN TODAY, 13 May 2002.

United States, Sri Lanka, Canada, and Singapore, with larger number of non-resident Indians, estimated at 16 million in the early 2000s (see Figure 1).

Besides, the Indian cinema is penetrating into the places without larger numbers of Indians. Since the 1950s Hindi films have been popular the former Soviet Union following close friendships formed during the Nehru era. Within Central Asia Hindi films still enjoy top billing with 
those produced in Russia, particularly within Uzbekistan and Kyrgyzstan. Although Indonesia has less than 30,000 Indian residents, a television channel has a weekly program of Indian films. Also the popularity of dubbed Indian films extends to Ghana and the Cameroons in West Africa.

Whatever the case may be, the universal popularity of Indian films is no secret: a simple storyline and a happy ending. Melodramas replete with songs and dances are a successful formula.

\section{Back run of capital to India}

\section{(1) Significance of the NRI taste}

The movie Muthu came to Japan directly from Tamilnadu via Singapore. Singapore is a multiethnic and multilingual country with Chinese, Malaya and Tamils. Therefore, television and cinema provide programs in their respective languages. Street names and those on the mass rapid transit system's stations are written in three languages. People of Indian descent in Singapore belong either to the business or laboring classes. Usually, those engaged in business belong to the Chettiyar caste. Yet, there are few cinemas in Singapore that exclusively screen either Hindi or Tamil films. Irrespective of their source, most new films are screened simultaneously with their release in India, without any time lag. Similar situations exist in both North America and England. On occasions, the release of new films is earlier in foreign countries than in India. Serious copyright problems are involved with these firms.

Furthermore, though Indian films are shown abroad, regionalism is still an important factor in attendances. As large numbers of Tamil immigrants live in Singapore, Malaysia and Sri Lanka, Tamil films are the prime focus of interest. In the Gulf countries the Malayalam films dominate as most of the migrants are from Kerala, particularly as their production is supported by capital from Gulf immigrants. Thus, Indians residing abroad exercise great power over the trajectory of India's cultural economy. Another example of such power is that successful businessmen of Indian origin in Singapore, Malaysia and Gulf countries, invest in their hometowns by constructing gigantic shopping malls, particularly in most metropolises with the sole exception of Madras where life still proceeds at a slower pace.

In this way the Indians who live abroad in the U.K. and, since the 1890s in Canada and the United States - the so-called non-resident Indians (NRI) - have started to exert a great influence on their native country. Their influence has now extended to new movies that are increasingly adopting NRI themes. This genre is typified by. Jeans (1998), which was also released in Japan. Jeans is a really bewildering and complicated film, which is set in Los Angeles where three couples play double roles. Simultaneously $A a$ ab laut chalen (1998) was released that was also set in California.

NRI interest is also reflected in fashion. The dress, which represents India, is, of course, the sari, especially in South India where traditional designs and dark shades are preferred. In contrast, the NRIs who live abroad prefer either combinations of colors and designs, or bright splendid colored saris, which are divorced from tradition. The saris that satisfy the tastes of NRIs are 
being introduced into movie scenes. For example, as actors in the movies wear jeans they have become very popular among NRI youth. Indeed, jeans have become so popular through television and movies that even high school girls, who once wore the Punjabi dress, salwar and khameez, wear them. Criticism that the younger generation may not even know how to wear the sari grows stronger everyday.

Foreign influences are accelerated through satellite broadcasts. Indian versions of channel V and MTV repeatedly broadcast hit-parade programs. Only a few years ago Pop was unknown and airplay was restricted to songs from films. In recent years independent popular music has appeared. Gradually, Indian Pop has emerged with an American overlay.

\section{(2) Beauty India}

Originally, cinema and fashion were deeply intertwined. Designers introduced new fashions through the cinema. Since the 1960s "celluloid fashion" has play the role of fashion leader. Once the $70 \mathrm{~mm}$ entered the cinema world the screen became larger and interest in promoting fashion through the screen increased. Since then celluloid fashion designers, notably Xerxes Pathena and Manish Malhotra have come to the forefront with their novel fashions. For example, the unknown graduation sari in which Kajol was wrapped in Kuch kuch hota hai (1999) has become very popular. In Singapore's Little India the "Kuch kuch hota hai saris" are displayed in fashion shop windows.

The sari is traditional Indian attire though its design and fashion are ever changing. Recently, designers based in Europe, notably Ritu Kumar, Ritu Beri and Tarun Tahiliani, have started to produce a new line of saris. Similarly, fashion for Indian men is also being transformed.

Moreover, a greater number of Indian beauties work abroad. Of course, since ancient times Indian women have had a reputation for beauty but they did not participate in beauty contests. After 1994 this situation has changed when Aisharya Rai became Ms. World and Sushmita Sen Ms. Universe. Subsequently, both Diana Hayden and Yukta Mukhay became Ms. World. In 2000 Indian beauties were crowned as Ms. World, Ms. Universe, and Ms. Asia Pacific. These beauty contest winners enjoy several privileges and inevitably film stardom awaits them with an enormous income. All winners of major beauty contests have entered the cinema. Maybe, this entry reflects how beauty contests mirror the nature of the Indian cinema. However, most current contestants are models who undergo both plastic surgery and style training. Although this transformation is suited to British and American tastes, the faces and style of the new generation of beauty contestants are slightly different from those used in the Indian cinema in the past.

\section{(3) Indian cinema, where to go?}

The surge in the distribution of Indian films abroad should provide the impetus for Indians to work in Hollywood. So far, Mira Nair and Shekar Kapur have resisted this logic. Mira Nair's latest production Monsoon Wedding (2001) won the Golden Lion in the International Film Festival at Venice. It is an American-Indian film devoid of Indian-ness. Should we describe it as a film aimed at enabling nostalgic NRIs to discover India? The film invokes a strange feeling as it blends both Eastern and Western relationships together. Unlike the Kamasutra, the film did not 
cause censorship issues, prohibitions of screenings or melees outside theaters. Rather it was a moderate film highlighting family love. In other words, it was very much focused on seeing India from an outside perspective.

Furthermore, A.R. Rahman directed the songs for the musical Bombay Dreams. The film's maiden screening was at the Apollo Victoria Theater in London's West End and intended for NRI. Yet, this production touched the hearts of both North American and Japanese audiences, reflecting their reputation as the world's greatest consumers of musicals. In 2004 Rahman, following the success of Bande Matram, was able to fulfill his long cherished dream of leaving India on one-way ticket to screen Bombay Dreams in America.

Having crossed the country's geographical borders, Indian cinema is entangled with complicated views of what is 'inside' and 'outside' the country. Also the cinema has traversed the whole spectrum of Indian society and is now expanding rapidly into a diversified world. This trend is not restricted to Indian cinema but also encompasses Indian culture.

With the onset of globalization, the identity of "Indian" cinema has become vaguer. Is the film Elizabeth directed by an Indian director an authentic Indian product? Is A.R. Rahman's Bombay Dreams an Indian musical? Even the Monsoon Wedding directed by Mira Nair, who was born in India, and played by Indian film stars, arouse a question of whether it is a genuine Indian film. Indian-ness in an age of globalization, lies in engendering nostalgic feelings throughout the Indian diaspora Thus, the Indian cinema has experienced radical changes as a consequence of globalization, the liberalization of India's political economy, and development of media technology. These developments have been associated with the rise of a new class of transnational cosmopolitan Indians, which are using the media, especially the cinema, to imagine and construct arcadias and utopias for themselves in both India and the world. Conversely, the imaged Indian-ness is likely to transmute into strong nationalist feelings, especially Hindu nationalism. This "glo-calization" process emphasizes local (regional and national) identities in an age of globalization.

(National Museum of Ethnology)

4) Inden, R., 'Transnational class, erotic arcadia and commercial utopia in Hindu films', (Brosius, C. and Butcher, M., eds., Image Journeys: Audio-Visual Media and Cultural Change in India. New Delhi: Sage, 1999), pp. xx-yy. 


\title{
Indian Cinema in an Age of Globalization
}

\author{
Sugimoto Yoshio \\ National Museum of Ethnology, Osaka, Japan
}

India is the world's largest film produser. This essay discusses the multi-lingual diversity and socio-political dynamics of Indian commercial cinema in the age of globalization, The three great urban centers of movie production are identified: namely, Mumbai (or Bombay) in the West, Kokotta (Calcutta) in the East, and Chennai (Madras) in the South, each with its own characteristics and impacts, domestically and abroad.

Next, the focus is placed on the influence of the new middle class that have come to the forefront of Indian urban life after the economic liberalization. Attention is centered on the impact of technological developmants such as cassettes, CDs, DVDs, and satellite TV on Indian cinema. Finally, the recent influence of overseas Indians, including non-resident Indians and persons of Indian origin, on the nature and direction of Indian cinema is discussed.

To conclude, the new class of transnational cosmopolitan Indians are using the media, especially the cinema, to imagine and construct utopias for themselves in both India and the world. Conversely, the imagined Indian-ness is likely to transmute into nationalist feelings, especially Hindu nationalism. This "glo-calization" process emphasizes local (regional and national) identities in an age of globalozation.

Key words: indian cinema, popular drama, multilingual, economic liberalizasion, nationalism, overseas Indians

\section{グローバル化時代におけるインド映画}

\section{杉本良男}

国立民族博物館

\footnotetext{
本論文では，インド映画の特徵およびその文化的特性，地域性，グローバル化の諸側面に注目す る。まず，(1)インドのメガ・シテイを舞台にした大衆演劇から娛楽映画への系譜，とくに，イギリ ス大衆演劇の影響を受けながら，インド神話・ペルシア神話を題材にとった大衆演劇の影響を直接 受けた独立前のインド映画の状況について紹介する。つぎに，(2)インド映画の多言語性，地域的多 様性について，とくに，20近い言語でつくられているインド映画の地域性と，とりわけ，政治との 関係が深かった南インドの政治的娛楽映画とナショナリズムとの関係について論じる。さらに，(3) グローバル化時代のインド映画について，とりわけ，1990年代のインドの経済自由化以後，グロー バル化の波に乗り，ハリウッドにも進出して世界を席巻しようとしているインド映画の現状と課題 についてそれぞれ述べる。

キーワード：インド映画, 大衆演劇, 多言語, 経済自由化, ナショナリズム, 在外インド人
} 